\title{
HEDONISM AND LUXURY FASHION CONSUMPTION AMONG BLACK AFRICAN WOMEN IN THE UK: AN EMPIRICAL STUDY
}

\begin{abstract}
Purpose: Although consumption is a universal phenomenon, it is characterised with considerable degree of diversity in relation to various factors such as culture, age, gender, ethnicity, and many others. Accordingly, more often than not, these factors underpin consumers' reactions to different market offerings including luxury products. While a plethora of scholarship effort are evident in the extant literature in regards luxury consumption, there is dearth of studies around how this is linked hedonism and ethnic consumers. Hence, this paper fills a palpable gap in the literature by exploring the UK Black African women's taste for luxury fashion consumption.
\end{abstract}

Design/Methodology/Approach: The study is interpretive in nature with the use of twenty indepth interviews conducted with Black African women through the use of snowballing and purposive sampling methods.

Findings: The study shows that the respondents' motivation for luxury consumption is driven by success and evolutionary motives, belongingness, societal pressures, cultural connection, anthropomorphism, consumer brand relationship and hedonism.

Originality/Value: Apart from the theoretical implication of the study which revolves around extending the discourse of taste in consumption and ethnic consumer behaviour, the paper will be greatly beneficial for marketing practitioners especially in the area of segmentation, targeting, and positioning vis-à-vis the marketing of luxury products.

Keywords: Luxury, Hedonic consumption, Black Africa, Women, Fashion, UK 


\section{INTRODUCTION}

Although consumption is ubiquitous, it is characterized with interesting patterns of diversity. Numerous scholarship efforts have pinpointed consumer diversity in various ways which revolves around a number of factors including gender, age, income, ethnicity and a host of others (Penaloza, 1994; Laroche et al., 2007; Deloitte, 2018; Gbadamosi, 2019). This indicates a need to be cautious in relying on the existing postulations without recourse to the subterraneous factors that distinguish them. For example, various changes across the marketing environment such as socio-cultural and economic factors all over the world make the term luxury to be in a state of flux. For instance, the separate contributions of various elements of consumption purposes, such as functional, symbolic, and experiential qualities as indicated by Berthon et al. (2009) is another indication of the nature of challenge associated with this line of enquiry. Accordingly, this study explores the underpinning issues around Black African women consumption of luxury fashion products in the UK. Specifically, the paper unpacks luxury and hedonic consumption in relation to fashion products among these women as a specific ethnic group using the United Kingdom as the contextual platform. So, the central questions addressed in the paper are as follows: (1) What are the motives behind the taste of Black African women in the UK for the consumption of luxury fashion products?; and (2) To what extent do Black African women in the UK consume luxury fashion? The rest of this paper is arranged as follows. The next section is entitled theoretical background and features a critical review of the extant literature around women's luxury consumption, hedonism, symbolic consumption, and Black African women consumption. This is followed by the methodology section which comes immediately before the summary of findings. The discussion, implications, limitation, and direction for further studies end the paper in respective order. 


\section{THEORETICAL BACKGROUND}

\section{A critical overview of Luxury Consumption}

Luxury is a popular construct in the academic literature (Han et al., 2010; Kapferer and ValetteFlorence, 2016; Kim et al., 2018; Pathak et al., 2019; Kapferer and Valette-Florence, 2019; Sharma et al, 2020). Interestingly, different academic disciplines such as Economics (Veblen, 1899); Sociology (Bourdieu, 1984), and History (Berry, 1994) have distinct views on the term. Hence, there is a lack of consensus on the definition of luxury (Heine, 2012, p. 1) which makes the concept a bit blurred. These days, consumers have become more affluent, thus making luxury a genre that is no longer the preserve of the upper class (Srinivasan et al., 2014) as more customers have improved on their financial status, low and middleclass consumers stepping up the status ladder. Even though luxury is stigmatized as a conspicuous maker of status, wealth and power (Wallpach et al., 2020) drawing from the leisure class (Veblen, 1902), consumers now have much more expendable earnings in contrast to previous cohorts which results in a tendency towards achieving exclusive needs and aspirations through experience (Backer et al., 2014). So, this explains why Yeoman and McMahon-Beattie (2010) opine that luxury is more about experience than about wealth. However, it is not inaccurate that luxury is linked to status, but the scope transcends the financial ramifications (Wilcox et al., 2009; Mrad et al., 2020) as these factors are interrelated to robustly define luxury (Danziger, 2005; Kapferer and Laurent, 2016; Polese, \& Seliverstova. 2020). Hence, today, the rich have no more a monopoly on the luxury goods (Bilge, 2015, p. 35). According to Savitha and Sathyanarayan (2014, p. 86) one of the utmost key factors leading to the actual growth of the luxury market is the introduction of luxury goods to the middle and upper-middle class. So, there is an increase in the share of the upper-middle class in luxury consumption pattern (Bilge, 2015).

Meanwhile, apart from awards, trophies and status symbols, luxury also covers offerings giving aesthetic experience and gratification (Danziger, 2005; Israel, 2003). As a 
result, the sales of luxury goods is fast growing and the industry has improved (Conlumino, 2014; Deloitte, 2018; Lee et al., 2020). Currently, the desire for luxury goods is increasing progressively. Research shows that luxury, especially fashion luxury items are mainly diffused from Western countries to the rest of the world (Das and Jebarajakirthy, 2020; The Business of Fashion, 2018). It seems reasonable to argue that consumers within those locations are more likely to be exposed to fashion luxury than their counterparts based outside of these settings. A study by Statista (2020) shows that the global luxury goods industry, which includes cars, jets, drinks, fashion, cosmetics, fragrances, jewellery, and handbags, has increased in value for many years. In Europe, it is estimated that by 2018 , UK will become the leading luxury industry (Conlumino, 2014). Similarly, in the United States, research has it that spending on luxury brands amounts to as much as $\$ 525$ billion per year (Bev and Zolenski, 2011) with female consumption rate accounting for over half of this (D’Arpizio, 2012). Collectively, study shows that millennials and Generation $\mathrm{Z}$ will represent more than 40 per cent of the overall luxury goods market by 2025, compared with around 30 per cent in 2016 (Deloitte, 2018). In 2010, a report showed that women consume an average of $\$ 100$ billion every year on luxury brands (Lemonides, 2010). These data could be considered dated; however, research shows that revenue in the luxury fashion segment amounts to US\$5,101m in 2020 . The market is expected to grow annually by 5.5\% (CAGR 2020 -2025) (Statista, 2020). The report also shows that the market's largest segment is the segment luxury apparel with a market volume of US\$3,450m in 2020. In global comparison, most revenue is generated in the United States (US\$24,039m in 2020), even at that, the UK market seem to be growing steadily (Statista, 2020).

With the economic uncertainty and currency fluctuations caused by the Brexit vote, it would have been assumed that the UK luxury market will be affected. However, data reveals that, in the last few years, luxury goods and brands continued to see growth in most categories, because 
of the weaker pound value which encouraged spending in the UK rather than abroad in addition to the fact that London has maintained its status as an international luxury shopping destination (Euromonitor International, 2020). Moreover, Mintel (2020) estimates that consumer spending on womenswear grew by only $1.4 \%$ in 2019 to reach $£ 29.3$ billion. These are considerable statistics and could be linked to the claim of Stockburger-Sauer and Teichmann (2013) that women are readier than men, to indulge in conspicuous consumption thereby spending large sums of money on conspicuous luxury brands. It has been identified that comparatively, the price for female luxury product is higher than that of men (Lemonides, 2010). However, this has not reduced the rate of female luxury consumption as shown in the high sales figures of brands such as Hermes, Louis Vuitton and Chanel which maintained a high sale volume (Forbes, 2009). In addition, luxury fashion consumption allows women to present and express themselves (Wilcox et al., 2009) as well as provide hedonic value and status than non-luxury (Prakash, 1992). So, it is logical to hold that women are directed to social and emotional relationships with others (Wang and Griskevicius, 2014); which could possibly explain why they use luxury products as 'signalling system' (Wang and Griskevicius, 2014).

Meanwhile, arguments in favour of the link between evolutionary psychology and consumer behaviour are evident in the literature (Backer et al., 2014; Colarelli and Dettmann, 2003). When relating evolutionary psychology to consumption behaviour, it is seen that generally, 'goods function as signals of desirable traits and bring status to the consumer' (Miller, 2000, p. 64). It has been argued that women use luxury brands as signals to other women for the purpose of creating impression about their relationships (Backer et al., 2014). This shows that women's flaunting of luxury possessions functions as an 'intra-sexual signalling system' (Wang and Griskevicuis, 2014) especially with regards to fashion luxury. Female consumers of luxury brands satisfy their feelings of pleasure and gratification through 
the luxury goods as these products will continue to enhance their charm for consumers (Yeoman 2011, p. 50). Basically, the traditional view on consumer behaviour shows that consumers act rationally when making consumption decisions, however in-depth studies on luxury consumption suggest that consumers do not always act rationally and may sometimes get completely emotive concentrating on the feelings like fun and pleasure to get through the consumption behaviour (Bilge, 2015; Polese, \& Seliverstova. 2020).). While these viewpoints have enriched our knowledge on luxury consumption, far little is known about how this is linked to Black ethnic women consumers and their hedonic consumption activities. Hence, this is a fertile research avenue with considerable opportunity to extent our knowledge in this research domain.

\section{Hedonism and Consumption: Integrative Perspectives}

From a broad perspective, hedonism revolves around pleasure seeking, self gratification and the pursuit of pleasure (Johnson et. al., 2018). Linking it to consumption provides consumers with experiential enjoyment and pleasure in multisensory, emotive aspects (Hirschman \& Holbrook, 1982), and can be definite as gratifying inherent motivations, such as the desire for self-expression (Aaker, 1999; Arnold and Reynold, 2003) and identity signalling (Belk, 1988). Invariably, it helps people communicate with others and show their personal tastes (Hirschman and Holbrook, 1982). Research shows that some products are primarily hedonic. Products such as fashion have personal and imperceptible features that can fulfil consumers' experiential needs, like gratification and pleasure, whereas primarily utilitarian products with tangible and objective features provide functional benefits and needs (Hirschman and Holbrook, 1982; Mano \& Oliver, 1993; Barnes and Lea-Greenwood, 2010; Barnes, 2013; Japura et al., 2018'). Comparatively, the benefits provided by utilitarian consumption are more concrete while the benefits of hedonic consumption are mostly experienced in an imperceptible form, this makes 
the consumption pattern more problematic to rationalise (Thaler, 1980; Hsee, 1996; Prelec and Loewenstein, 1998).

Hedonism labels those characteristics of consumer behaviour that relate to the multi-sensory, fantasy and emotive facets of a person's experience with products (Hirschman and Holbrook, 1982, p. 92). These three phenomena are all linked together to create a favourable experience of a product or brand. While the three facets work hand in hand, multi-sensory consumption involves multiple psychological senses which include smell, sight, hearing, touch and taste. These senses work together to frame our experience of the world, which creates a strong, logical and consistent understanding of our environment (Fulkerson, 2009, p. 1). While Hirschman and Holbrook (1982) argue that these experiences are inwardly framed and born from an inner desire, Berlyne (1971) in an earlier presentation presents an internal experience of multi-sensory impulses as an essential form of consumer response. For example, perceiving a perfume may cause a consumer to react not only to the smell but also to create internal imagery consisting of sights, sounds and tactile sensations, all of which are also experienced (Hirschman and Holbrook, 1982, p. 92). Although significant scholarship effort has been made around hedonism (See for example, Hirschman and Holbrook, 1982; Fulkerson, 2009; Adomavicuite, 2013), many questions remain unanswered, particularly with regard to understanding the sources of pleasure, and the manner in which Black African women seek it, and the ways in which this aspect impacts on their luxury fashion consumption..

Two types of multisensory images often discussed around hedonism are historic imagery and fantasy imagery. The historic imagery links a consumer to a past episode while fantasy imagery happens when the consumer's response is not drawn from experience (Singer, 1966). Hedonic items are mostly used up in sensual fulfilment and emotional drives (Woods, 1960) or pleasurable and delightful motives (Holbrook, 1986). Hence, these hedonic elements 
produce emotive stimulation (Mano and Oliver, 1993) with benefits that are appraised mainly on a sense of taste, attractiveness, symbolic meaning and sensory experience (Holbrook and Moore, 1981). All forms of consumer experiences ranging from pleasure, fun, entertainment, fantasies and unpleasant feelings are linked to the hedonic aspect of consumption (Adomavicuite, 2013).

Meanwhile, the emotional connections consumers have with brands are seen to result in brand relationships (Fitzmaurice, 2005). Authors seem to agree that consumers form an emotional bond with the brands they have experienced. When the experience is favourable, it results in a long-term affair (Luomala and Laaksonen, 2000; Barone et al., 2000; Fitzmaurice, 2005; Wood and Rettman, 2007). The long-term bond between consumers and brands became widespread as consumer-brand relationships strongly came to the limelight in the eighties (Raut and Brito, 2014; Fritz et al. 2014; Ghani and Tuhin, 2016).

Extant literature shows that hedonic consumption is amenable to both men and women, however, women are perceived to be more driven by this phenomenon than men (Oktem et al., 2017). Chang et al. (2004) reveal that hedonic values have direct impact on female consumers. These findings are linked to the work of Özdemir and Yaman (2007), who note that hedonic shopping behaviour is different between genders. The reason for this difference is that female consumers regard shopping as an action of pleasure while male consumers are more driven by the rational and functional benefit of a product. For examples, studies have linked women to hedonism (Aytekin and Ay, 2015; Fettahlıoğlu et al., 2014; Aydin, 2010). It has been noted that hedonic consumption causes excitement and women can act dynamically towards achieving this feeling in shopping (Colls, 2004). From a historical point of view, Bailey states that 'each good needs to make people believe it is a kind of hedonism before becoming a desired luxury'. The requisite connection with luxury and hedonism explains why luxury is 
enjoyed (Bailey, 2005). However, the extent to which these are linked to Black African women remains a gap in the literature.

\section{Black African Women Consumption: A Conceptual overview}

Studies integrate the ethnicity of minority consumers, particularly how their ethnic identification and association would impact on their values, attitudes, media usage, perceptions of product attributes, brand loyalty and consumption of convenience and traditional food (Desphande et al., 1986; Laroche et al., 1998; Donthu and Cherian, 1994; Afridi et al., 2020). Meanwhile, evidence shows that young Black African women have high educational, occupational and brand aspirations (Mirza, 1992). They are very likely to aspire to high social status jobs, and their choices are independent of parental influence. Furthermore, the aspiration of a Black African woman (Mirza, 1992) stems from her awareness of the society and the age she lives in, as well as self-realisation and consciousness. A South African report shows that a Black African woman is conscious, enlightened and more aware of her environment than ever (Flax, 1990; Preez and Visser, 2003). Consequently, it could be stated that the Black African woman is regarded as a new intelligent consumer (Johnson and Learned, 2004) whose consumption of fashion brands starts early in her life cycle.

A study on Black African women and clothing consumption reveals that several factors can influence what Black African women buy (Gbadamosi, 2012). This study shows social factors as crucial influence on Black African women's consumption style. Within social factors, the need for the women to conform to society's expectations stimulates their purchase behaviour. Moreover, it is shown that Black African women have an immense spending power with regards to the 'aspirational market' and, as a result, they are labelled as 'aspirational consumers' (Baronowski and Bemporad, 2014; Allemann, 2000, p. 52). Globally, aspirational consumers are the largest market segment at thirty-nine percent (39\%) of the population with 
up to two billion people (Baronowski and Bemporad, 2014). Statistically, accounting for more than half of this segment are female consumers at fifty-seven percent (57\%) (Allemann, 2000). Interestingly, aspirational consumers are regarded as those who are the first to 'unite materialism, sustainability and cultural influences' (Gauvin, 2014). They are most driven to buy items that will connect to 'their aspirations of creating a brighter future for them and the society' (Gauvin, 2014, p. 1) and 'engage in partnering with brands that help them make a difference with their actions' (Baronowski and Bemporad, 2014, p. 1). While these are enlightening to an extent, the notions of luxury and hedonism have not been unpacked vis-vis Black African women in the UK. Hence, this research aims to investigate this lacuna.

Emphatically, it is interesting to note that despite the immense spending power of the Black African woman (Baronowski and Bemporad, 2014) and the growth of Black African women in London (Coombs, 2014), there is still an unclear theoretical position regarding their luxury fashion consumption behaviour in London. Furthermore, given the growing consensus around a feminised fashion sector, as revealed by several studies (Bruce and Pakinson-Hill, 1999; Ives, 1999; Cassil, 1990), efforts to understand the taste and motives for the consumption of luxury fashion brands by women have been overlooked by researchers.

\section{METHODOLOGY}

From the philosophical standpoint, this study is interpretive in nature. Expectedly, the associated epistemological assumption is that social sciences and natural sciences differ, thus research procedure should take these differences into consideration by adopting appropriate strategies that account for this (Bryman and Bell, 2015). This methodological stance indicate that social analysis represents profound scepticism towards claims of objectivity and a privilege 
access to knowledge (Clarke, 2009, p. 29). Accordingly, it is mainly focussed on having a grasp on the reason, meaning and the motives for every behaviour (Collin and Hussey, 2009). Based on the objective of the study, the data was collected from 20 Black African women in the UK in the form of in-depth interviews through the use of snowballing and purposive sampling methods. The duration of the in-depth interviews was between 50 to 60 minutes and the participants were aged between 20 and 60 years. 12 respondents were full time income earners with an annual income of between $£ 20,000$ to $£ 45,000$ while 5 were full time students and the other 3 were self-employed with income of about 10,000 to 20,000 pounds per annum. The sufficiency of the data collected was determined with the theory of theoretical saturation which is the stage when no new idea was forthcoming with the inclusion of another observation (Strauss and Corbin, 1998).

This research adheres to the rules of informed and voluntary consent. For this, all participants were given a consent form prior to the research which explains the purpose of the study, the rights of the participants and contacts of key persons when any issue that require actions or clarifications arises. Moreover, confidentiality of information shared and anonymity of research participants are maintained. Prior to data collection, participants were informed of how confidential their information will be and assured of anonymity. In addition to this, the safety of all participants was maintained as they were assured before the commencement of the study. All events were recorded via tape recorder. Data collected was stored, transcribed and analysed using the conventional (inductive) content analysis which was done manually, meticulously, and critically. The coding process involved both initial and focused coding, as well as memos. Research findings were categorised into various themes for clarification, all aimed at addressing the research questions, aims and objectives.

\section{SUMMARY OF FINDINGS}


This study shows the interlocking pattern of link between hedonism among respondents and several other themes, which are motives for luxury consumption, societal pressures, consumer brand relationship, anthropomorphism, brand and consumer personality, belongingness, and societal pressures. They are interconnected and emerged as a pattern in the form of Social influence, Brand/personality, and Success and evolutionary motives for luxury consumption. These are now presented below.

\section{Success and evolutionary motives for Luxury Consumption}

It is interesting to note that factors like status, mating and making friends emerged as the essential motives concerning Black African women's luxury consumption. These motives help in explaining consumer attitudes through the evolutionary perspective. This study reveals how participants link their luxury consumption habits to status; and the need to belong to a particular social class. As revealed by these participants, they often associate luxury fashion consumption with the feeling of success, which eventually grows into a belief that shapes their attitudes.

'How you portray yourself how you are addressed, how successful you are, and it even determines the people you attract. People always want to be around successful people. The one-way people can tell how successful you are is in how much you display luxury items. They'll relate with you based on how classy you appear. It is worse on social media, if you do not display anything luxury, it just means you can't afford it' (Respondent 6, Age 20-25).

All respondents agree with the idea around success and luxury owned items and support the notion that success and luxury consumption can be linked together.

Additionally, people want to be identified as affluent as well as be associated with wealthy people, they are drawn towards items that assist them achieve such goals. The awareness of 
self and society prompts an inner desire to purchase brands that can reflect who they are and what class they belong to which portray them as successful. Consuming conspicuously is motivated by class, status and/or the need to make statement and stay relevant within the society. It also serves as a measure for reinforcing and recreating identity.

'That doesn't sound like a question to me, well the question should be why buy a luxury brand when you really don't want to display your worth? I mean that's why I buy what I buy like Christian Louboutin. When I wear the shoes, you need to see the way people look at me, the number of likes I get on my Facebook Page amazes me. People just know where you belong with what you wear. I am particular about stating clearly where I belong, what I mean is the class I belong to. It's called status symbol (Respondent 2, Age 30-35).

\section{Societal Pressure}

This research reveals societal pressure as a significant factor in consumption behaviours with regards to luxury products among these Black African women. Although they reflect on self as a motivational factor in consuming conspicuously, they also acknowledge the prominence of societal pressures in the scenario. As shown in this study, this societal pressure influences their taste for luxury which is linked to celebrity lifestyle and the need to be like them. By and large, these influences are linked to the society and its expectation on women.

- 'This is society, we belong to it and we are judged by it. All they want to see is that you conform to it. This is a big motivator I will say. You want to look and represent yourself well so that you don't get judged wrongly. This puts a lot of pressure people not me because I have grown pass that stage. But the need to belong, they need to be accepted and so on is driving people towards this. I see how my daughter glues to what Adele wears or Beyonce. They want to be like that because the society has made them believe that's the ideal. Gradually you become like it' (Respondents 10, Age 46-48). 
- 'The society we live in structures a lot of things, who you are to what you wear. The pressure becomes an influence. Social media platforms are there to always tell you what to and what not to wear. I follow a lot of fashion bloggers, when I see what they wear it gives me an idea of what I can wear. (Respondents 5, Age 46-48).

- Luxury fashion bloggers motivate me and most times I think of how to be like them, this thought drives me to wear what they wear. I understand that social media is full of lies but no matter how much lies they have going on there I still want to wear what I see others wear. People live fake lives just to belong to the setting. Well for me it spurs me to get the real item'. (Respondents 7, Age 20-25).

Societal pressure is applicable to all the respondents as they all mentioned that the society impacts their lifestyle, taste and approach towards luxury.

\section{Consumer Brand Relationship and Hedonism}

Participants displayed emotional connection with luxury fashion brands vis-a-vis their experience. The study reveals a clear emotional display by the participants, as the tone of admiration and attachment to brands were evident during the discussion. While some use the word 'love' to state their connection categorically, others use words such as 'passionate', 'satisfaction' and 'trust'.

'Like this watch, I am putting on I've had it for more than fifteen years, and that's the only watch I have; some people would have had like about ten. It is durable. When I bought this watch, I paid about 800 plus for it then, but now if you go to the market Raymond Weil, is about 1,000 plus. It's about what you love and [feel] attached to, as well and what it means to you. So, for me, it means the feeling of attachment, that sense of satisfaction that I think no other brand can meet' (Respondent 1, Age, 45-50).

Furthermore, consumers form relationships with these luxury brands when they realise the relationship is metaphorically mutual. The consumer becomes attached and the brand serves 
the purpose of consumption through personality connection, in terms of how the brand connects to their personality. All respondents show this relationship based on how positive they are about the connection with their favourite brands.

\section{Anthropomorphism, Brand and Consumer Personality}

As a result of the relationship, respondents tend to attribute human qualities to brands... Words like 'bae', were used in relationships to emphasise spouse or partner. This anthropomorphism is clearly expressed in what participants say about the brands, how they treat them and how they expect others to handle them. They pay particular attention and care to their luxury fashion possessions and derive pleasure from the brands. Apart from associating human attributes to luxury fashion brands, but they also treat them with special care:

'Brands speak, but Saint Laurent speaks better' (Respondent 10, Age, 30-35).

'She means everything to me - when I say everything, I mean everything. I take it personally when my sisters don't understand how much she means to me. Sometimes my sisters use this particular bag just anyhow, so to avoid any damage I keep away from people’ (Respondent 16, Age, 40-45).

By and large, linking human attributes to brands was evident among all participants in such a way that demonstrates the bond existing between them and their favourite luxury fashion brands.

\section{Belongingness}

The study reveals that because consumers are part of a society, they have need to be affiliated to members both in the online platforms and offline. In this research, the need to belong is incited by reference groups and evident in the luxury consumption of Black African women consumers. These groups could consist of family, friends and in some cases online interactions. 
When these women see what they like in others, they are driven towards associating with such individuals. To belong to such groups, they buy items that can facilitate the process thereby consume conspicuously:

'I just love to be like every other wealthy person out there. It doesn't matter how I attend to this, what matters is achieving this goal. If you are in Rome, one must act like the Romans in order to gain acceptance. I long to be a part of that rich society, that is why I can save up for a long time to get the items I need to achieve this' (Respondent 3 Age 35-37).

\section{Cultural Connection}

This study also reveals that, conspicuous consumption is a tradition that is embedded in the culture as participants stressed that it is a way of life, and quite reasonable for a Black African woman to wear luxury fashion brands. This behaviour can be linked back to the history of passing on luxury items from generation to generation, as they are motivated to buy products that are durable. They express how this buying behaviour defines who they are and portrays their identity. They also indicate that it is an attitude rooted in them and that this begins early in life. Black African women see it as unnatural for a Black African woman not to be conscious of what she wears.

The study indicates that the Black African woman is aware of her environment and tries to live favourably in it, irrespective of stereotypes and marginalisation. This group of consumers use brands that can help represent who they are to others. Findings suggest that selfconsciousness could lead to aspiration towards products that enhance the self.

'I am black and a typical Nigerian babe. Do you want to prove a point? Do not buy me flowers or box of chocolate. That does not move a real black woman. A real Black African woman loves the style; it is in our DNA, buy me Givenchy, Gucci and some of those badass luxury products. That is who we are, and I am proud to be one. I wear 
many luxury brands, and I love them as gifts too. All these flowers that people throw around White babes do not freak us. That is not how we roll' (Respondent 18, Age, 25$30)$.

The link between culture and taste for luxury fashion items is seen in all respondents. While participants between the ages of 20 to 30 are particular about how luxury fashion reflects who they are, participants above 35years' taste is drawn towards luxury as a heirloom rooted in the African culture.

\section{DISCUSSION AND IMPLICATION OF THE STUDY}

This study explores hedonism and its link to Black African women's consumption of luxury fashion products. It shows that luxury fashion consumption of Black African women is influenced by a number of interconnected factors which basically include evolutionary motives and consumer brand relationship. The study indicates that in consuming luxury brands, themes such as: success, societal pressure, anthropomorphism, belongingness, cultural connection, consumer behaviour and hedonism play considerable role in the Black African women's consumption of luxury products in the UK. Griskevicius and Kenrick (2013) propose a fundamental motive framework which upholds that humans have natural psychological variations for solving a set of specific ancestral social challenges. These social challenges include: making friends, evading physical harm, attaining status, avoiding disease, acquiring and keeping a mate and caring for family (p. 372). In an attempt to confront these challenges, consumers engage in behaviour that can help facilitate solutions for managing them which in this context is about luxury consumption (Shao et al., 2019; Kapferer and Valette-Florence, 2019; Lee et al., 2020). The consumption of luxury items serves as an aid for these Black African women consumers in managing societal expectations, which end up as motives for conspicuous consumption. Fundamental motives have been extensively studied by authors 
such as Griskevicius and Kenrick, (2013),, Kenrick et al., (2010); Griskevicius et al., (2009) and Saad, (2007). These authors link fundamental motives to both human motives and human psychology. Although these motives have been discussed within consumer behaviour (Griskevicius and Kenrick, 2013), this research supports the existence of the theory as an implication for consumption and choice, product preference as well as one of the factors considered crucial within the Black African woman's motive for the consumption of luxury fashion brands. Furthermore, the need to make statement about oneself, emotional bond with brands help consumers cope with societal pressure. Fundamentally, hedonism moderates the impact of these factors on how Black African women consumer luxury products and brands. This study indicates that when dealing with Black African women and luxury consumption, these themes have significant impact.

This paper has substantial implications for marketing both in the managerial and theoretical contexts which emphasise its value as a new study. In the theoretical context, it enhances the existing studies on luxury consumption patterns, taste, ethnicity and hedonism as well as extends understanding on women's consumption of luxury brands. Although authors have explored women's consumption of luxury brands (Wang and Griskevicius, 2014; Stockburger-Sauer and Teichmann, 2013; Lemonides, 2010) in some way, this study extends this to other valuable areas which are hedonism and ethnic minority context.

Furthermore, this study fills some gaps in the literature and implies that luxury marketing managers targeting ethnic minority women in the UK could use the findings of this study to design their marketing strategies especially in the area of co-creation of luxury products and segmentation, targeting, and positioning. Fundamentally, the notion of value varies with different consumer segments in terms of what they crave and the factors propelling them in making the relevant choices. For example, a number of factors such as age, gender, income, occupation and many others have been used to explain consumption pattern. In its 
practical sense, this study provides strategic direction to luxury marketing managers on how to design their strategies in a more focussed form towards reaching the markets in micro forms especially in relation to Black African women. The study cautions again undue generations and offers a more focussed approach to luxury brands marketing management. With this, marketing resources will be more efficiently and effectively managed.

\section{Limitations of the study and Avenue for further research}

Although this research is reasonably telling in relation to Black African women's luxury consumption behaviour, it also has some limitations that provide guidelines for future research on the topic. One of the limitations of this study is that which is associated with all qualitative studies - small sample size. This restricts the level to which the findings can be generalised to the wider population of this ethnic minority group. However, since this research is not aimed at testing any hypothesis but to create an in-depth and detailed understanding of this topic, this issue of the small sample size may not be very persuasive. Similarly, the study is focussed on women in a particular ethnic group. Hence, future studies could consider investigating this phenomenon within a different ethnic group and among men. This could extend the extant knowledge on the vital role of ethnicity and gender in relation to these reported findings. 


\section{References}

Aaker, J. L. (1999). The malleable self: The role of self-expression in persuasion. Journal of marketing research, 36(1), 45-57.

Adomaviciute, K. (2013) 'Relationship between Utilitarian and Hedonic Consumer Behaviour and Socially Responsible Consumption', Economics and Management, 18(4), pp. 754-760.

Afridi, M. A., Tahir, M., Sayal, A. U., \& Naseem, I. (2020). 'Migration enclave and downward economic growth in Africa'. International Journal of Social Economics. Vol. 47 No. 12, pp. $1527-1540$

Allemann, L. (2000) 'The African dream', Marketing Mix, 18(5), pp. 51-55.

Arnold, M. and Reynolds, K. (2003). Hedonic shopping motivations. Journal of Retailing, 79, (2), 77-95

Aytekin, P. \& Ay, C. (2015). Hedonik Tüketim ve Anlık Satın Alma İlişkisi. Niğde University Faculty of Economics and Administrative Sciences Journal, 8, (1), 141-156.

Aydin, N. (2010). Subjective well-being and sustainable consumption. The International Journal of Environmental, Cultural, Economic and Social Sustainability, 6(5)., pp. 131 -147

Backer, C., Fisher, M., Hudders, L. and Vyncke, P. (2014) 'The Rival Wears Prada: Luxury Consumption As A Female Competition Strategy', Evolutionary Psychology, 12(3), pp. 570587.

Bailey, C. (2005) A guide to qualitative field research. Sage Publications.

Barone, M., Miniard, P. and Romeo, J. (2000) 'The influence of positive mood on brand extension evaluations', Journal of Consumer Research, 26, pp. 386-400.

Barnes, L., \& Lea-Greenwood, G. (2010). "Fast fashion in the retail store environment." International Journal of Retail \& Distribution Management, 38(10), 760-772. Barnes, L. (2013). “Fashion marketing”. Textile progress, 45(2-3), 182-207. 
Baronowski, M. and Bemporad, R. (2014) 5 Secrets to engaging aspirational consumers Available at: fastcoexist.com. (Accessed: $17^{\text {th }}$ January, 2015).

Belk, R. (1988) 'Possessions and the Extended self', Journal of consumer research, 15(9), pp. 139-168.

Berlyne, D. (1971) Aesthetic and Psychology, New York: Meredith Corporation.

Berthon, P., Pitt, L., Parent, M., \& Berthon, J. P. (2009). Aesthetics and ephemerality: Observing and preserving the luxury brand. California management review, 52(1), 45-66.

Berry, S. (1994) 'Estimating discrete-choice models of product differentiation', The Rand Journal of Economics, 25(2), pp. 242-262.

Bev, J. and Zolenski, V. (2011) Braking into and succeeding as handbag designer, Start handbag business. Available at http://stylecarer.com/handbag-designer/. (Accessed: 21st August 2014).

Bilge, H. A. (2015). Luxury consumption: literature review, Khazar Journal of Humanities and Social Sciences, 18(1), 35-54

Bourdieu, P. (1984) Distinction: A social critique of the judgement of taste. Available at: http://www.mit.edu/ allanmc/bourdieu1.pdf. (Accessed: $24^{\text {th }}$ November 2014).

Bruce, M. and Parkinson-Hill, J. (1999) 'New trends in fashion: street wear clothing', Journal of fashion marketing and management, 3(3), pp. 272-281.

Bryman, A. and Bell, E. (2015) Business Research Methods, 4th edn. Oxford: Oxford University Press.

CAGR (2020) Global apparel market CAGR from 2015 to 2020, by region. [ONLINE] Available at https://www.statista.com/statistics/821513/global-apparel-market-growthforecast/. Accessed $11^{\text {th }}$ December 2020 
Cassill, N. (1990) 'Employment orientation of women as a market segmentation variable for apparel', Clothing and textile research journal, 9(1), pp. 59-64.

Chang, L. Burns, L. and Francis, S. (2004) Gender Differences in the dimensional structure of Apparel shopping satisfaction among Korean consumers', The role of hedonic shopping value, clothing and textiles Journal, pp. 1-30

Clarke, C. (2009) 'Paths between positivism and interpretivism: an appraisal of Hay's via media. Politics. 29(1), pp. 28- 36.

Colarelli, S. and Dettman, J. (2003) 'Intuitive evolutionary perspectives in marketing practices', Psychology and marketing. 2(1), pp. 1-12.

Collis, J. and Hussey, R. (2009) Business Research. Palgrave Macmillan.

Colls, R. (2004). 'Looking alright, feeling alright': emotions, sizing and the geographies of women's experiences of clothing consumption. Social \& Cultural Geography, 5(4), 583-596.

Conlumino (2014) UK set to become largest luxury goods market in Europe by 2018. Available at: http://conlumino.com/?p=1583. (Accessed: $5^{\text {th }}$ September, 2017)

Coombs, K. (2014) Up to 30\% of UK population will be from ethnic minorities by 2050-Study. Available at: http://rt.com/uk/157012-britain-ethnic-minorities/. (Accessed: $12^{\text {th }}$ December, 2014).

D’Arpizio, C. (2012) Luxury goods worldwide market study, spring 2012 update, Bain and Company. Available at: http://www.bain.com/about/press/press-release/luxury-goods-marketpredicted-to-grow-six-seven-percent-in-2012.aspx. (Accessed: 21st August 2014).

Das, M. and Jebarajakirthy, C. (2020) Impact of acculturation to western culture (AWC) on western fashion luxury consumption among Gen-Y consumers in the Asia-Pacific region. Journal of Retailing and Consumer Services, 56, pp. 1-17 
Danziger, P. (2005) let them eat the cake: Marketing luxury to the masses as well as the classes. Chicago. Dearborn Trade Publishing.

Das, M. and Jebarajakirthy, C. (2020) Impact of acculturation to western culture (AWC) on western fashion luxury consumption among Gen- Y consumers in the Asia-Pacific region', Journal of retailing and consumer services, 56, pp. 1- 17

Deloitte (2018) Global Powers of Luxury Goods 2017: the new luxury consumer. Available at https://www2.deloitte.com/content/dam/Deloitte/global/Documents/consumer-industrialproducts/gx-cip-global-powers-luxury-2017.pdf. (Accessed: $4^{\text {th }}$ September, 2018).

Deshpande, R., Wayne, H. and Naveen, D. (1986). “The Intensity of Ethnic Affiliation: A Study of the Sociology of Hispanic Consumption," Journal of Consumer\&search, 13(September): 214-220.

Donthu, N. and Cherian, J. (1994) 'Impact of Strength of Ethnic Identification on Hispanic Shopping behaviour', Journal of Retailing, 70(4), pp. 383-393.

Euromonitor International (2020) Luxury goods in the United Kingdom. [ONLINE] Available at https://www.euromonitor.com/luxury-goods-in-the-united-kingdom/report. (Accessed $2^{\text {nd }}$ December 2020)

Fettalığlu, H., Yıldız, A. and Birin, C. (2014). 'Hedonik Tüketim Davranışları: Kahramanmaraş Sütçü İmam University ve Adıyaman UniversityÖğrencilerinin Hedonik Alışveriş Davranışl Demografik Faktörlerin EtkisininKarşılaştırmalı Olarak Analizi', The Journal of Academic Social Science Studies, International Journal of Social Science, 27,pp. 307-331 
Flax, J. (1990) Postmodernism and gender relation in feminist theory. New York and London: Routledge.

Forbes (2009) World's most powerful luxury brands. Available at: http://www.forbes.com/2009/05/01/powerful-luxury-brands-lifestyle-style-luxurybrands.html. (Accessed: $1^{\text {st }}$ April 2014).

Fitzmaurice, J. (2005). 'Incorporating consumers' motivations into the theory of reasoned action', Psychology and Marketing, 22(1), pp. 911-929.

Fritz, W., Lorenz, B., Kempe, M. (2014) 'An extended search for generic consumer-brand relationships', Psychology and Marketing, 31(11), pp. 976-991

Fulkerson, M. (2009) Explaining Multisensory Experience. Available at: http://philosophy.ucsd.edu/_files/facultysites/mfulkerson/explaining-multisensoryexperience.pdf. Accessed $5^{\text {th }}$ May 2015

Gauvin, J. (2014) The Aspirational Consumer and the Future of the Customer Experience. Available at: http://www.execsintheknow.com/the-aspirational-consumer-and-the-future-ofthe-customer-experience/. (Accessed: $18^{\text {th }}$ January, 2015).

Gbadamosi, A. (2012) 'Acculturation: an exploratory study of clothing consumption among Black African women in London, UK', Journal of fashion marketing and management. 16(1), pp. 5-20.

Gbadamosi, A. (2019), 'Postmodernism, ethnicity, and celebrity culture in women's symbolic consumption', International Journal of Market Research, DOI: 10.1177/1470785319868363

Ghani, B. and Tuhin, M. (2016) 'Consumer brand relationships', International Review of Marketing 6(4), pp. 950-957 
Griskevicius, V. and Kenrick, D. (2013) 'Fundamental Motives: how evolutionary needs influence consumer behaviour', Journal of Consumer psychology, 23(3), pp. 372-386.

Griskevicius, V., Tybur, J., Kenrick, D., Steven, G., Shapiro, J. and Perea, E. (2009). Aggress to Impress: Hostility as an Evolved Context-Dependent Strategy: Interpersonal Relations and Processes. Journal of Personality and Social Psychology, 96(5), pp. 980- 994.

Han, Y. J., Nunes, J. C., \& Drèze, X. (2010). Signaling status with luxury goods: The role of brand prominence. Journal of marketing, 74(4), 15-30.

Heine, K. (2012) The concept of luxury brands. Available at: www.conceptof luxury.com. (Accessed: 06 ${ }^{\text {th }}$ June 2015).

Hirschman, E. C., \& Holbrook, M. B. (1982). Hedonic consumption: emerging concepts, methods and propositions. Journal of marketing, 46(3), 92-101.

Holbrook, M. and Moore, W. (1981) 'Feature interactions in consumer judgments of verbal versus pictorial representations', Journal of Consumer Research, 8(1), pp.103-13.

Holbrook, M. (1986) Emotion in the consumption experience: towards a new model of the human consumer, The role of affect in consumer behaviour: emerging theories and applications. MA: Lexington Books.

Hsee, C. K. (1996). Elastic justification: How unjustifiable factors influence judgments. Organizational Behavior and Human Decision Processes, 66, 122-129.

Israel, B. (2003) Bachelor Girl: The Secret History of Single Women in the 20th Century. London: William Morrow and Co London

Ives, V. (1999) 'Black magic. Is the black middle- class consumer out there?, Marketing mix, 17(7), pp. 26-32. 
Japutra, A., Ekinci, Y., and Simkin, L. (2018). Positive and negative behaviours resulting from brand attachment: The moderating effects of attachment styles. European Journal of Marketing, 52(5/6), 1185-1202.

Johnson, C., Tanqi, A. and Baker, T. (2018) From Gucci to green bags: conspicuous consumption as a signal for pro-social behaviour,' Journal of Marketing theory and Practice, 26(4), pp. 339-356

Johnson, L. and Learned, A. (2004) Don't think pink: what really makes women buy and how to increase your share of this crucial market. New York: Amacom.

Kapferer, J. and Valette-Florence, P. (2019). How self-success drives luxury demand: An integrated model of luxury growth and country comparisons. Journal of Business Research, 102, 273-287.

Kapferer, J. and Laurent, G. (2016). Where do consumers think luxury begins? A study of perceived minimum price for 21 luxury goods in 7 countries. Journal of Business Research, 69(1), 332-340.

Kapferer, J. and Valette-Florence, P. (2016). Beyond rarity: the paths of luxury desire. How luxury brands grow yet remain desirable. Journal of Product \& Brand Management.

Kenrick, D., Nieuweboer, S. and Buunk, A. (2010) Universal mechanisms and cultural diversity: Replacing the blank slate with a colouring book. New York: Psychology Press.

Kim, J. C., Park, B., \& Dubois, D. (2018). How Consumers' Political Ideology and StatusMaintenance Goals Interact to Shape Their Desire for Luxury Goods. Journal of Marketing, $82(6), 132-149$. 
Laroche, M., Yang, Z., Kim, C., \& Richard, M. O. (2007). How culture matters in children's purchase influence: a multi-level investigation. Journal of the Academy of Marketing Science, 35(1), 113-126.

Laroche, M., Kim, C., \& Tomiuk, M. A. (1998). Italian ethnic identity and its relative impact on the consumption of convenience and traditional foods. Journal of Consumer Marketing. Vol. 15 No. 2, pp. 125-151.

Lemonides, D. (2010) Niche marketing: the spending power of women, Verve marketing and design. Available at: https:luxurysociety.com/articles/2010/02/niche-marketing-the-spendingpower-of-women. (Accessed: $4^{\text {th }}$ December, 2014).

Lee, H., Rothenberg, L., \& Xu, Y. (2020). Young luxury fashion consumers' preferences in multi-channel environment. International Journal of Retail \& Distribution Management.

Luomala, H. and Laaksonen, M. (2000) 'Contributions from mood research', Psychology and Marketing, 17, pp. 195-233.

Mano H, and Oliver, R. (1993) 'Assessing the dimensionality and structure of the consumption experience: evaluation, feeling, and satisfaction', Journal of Consumer Research, 20(1), pp. $451-66$.

Miller, G. (2000) 'Mental traits as fitness indicators: expanding evolutionary psychology’s adaptationism', Annals of the New York academy of sciences. 907(2), pp. 62-74.

Mintel Report (2020) UK Womenswear Market Report. [ONLINE] Available at https://store.mintel.com/uk-womenswear-market-report. (Accessed $2^{\text {nd }}$ December 2020)

Oktem, T., Oktem, G. and GENC, I. (2017), Review of the Hedonic Consumption Perceptions Based on Gender and Shopping Habits of Undergraduates, International Journal of Science Culture and Sport, 5(1), pp. 20 -26 
Mirza, H. (1992) Young, female and Black. London and New York: Routledge.

Mrad, M., Majdalani, J., Cui, C. C., \& El Khansa, Z. (2020). Brand addiction in the contexts of luxury and fast-fashion brands. Journal of Retailing and Consumer Services, 55, 102089.

Özdemir, Ş. \& Yaman, F. (2007) “Hedonik Alışverişin Cinsiyete Göre Farklılaşması Üzerine Bir Araştırma” Eskişehir Osmangazi University, IIBF Magazine, 2(2), 81-91.

Penaloza, L. (1994). Atravesando fronteras/border crossings: A critical ethnographic exploration of the consumer acculturation of Mexican immigrants. Journal of Consumer Research, 21(1), 32-54.

Pathak, A., Velasco, C., Petit, O., \& Calvert, G. A. (2019). Going to great lengths in the pursuit of luxury: How longer brand names can enhance the luxury perception of a brand. Psychology \& Marketing, https://doi.org/10.1002/mar.21247

Polese, A., \& Seliverstova, O. (2020). Luxury consumption as identity markers in Tallinn: A study of Russian and Estonian everyday identity construction through consumer citizenship. Journal of Consumer Culture, 20(2), 194-215.

Prakash, V. (1992) 'Sex roles and advertising preferences', Journal of advertising research, 32(3), pp. 43-52.

Preez, R. and Visser, E. (2003) 'Apparel shopping behaviour- part 2: conceptual theoretical model, market segments, profiles and implications', Journal of industrial psychology, 29(3), pp. $15-20$.

Prelec, D., \& Loewenstein, G. (1998). The red and the black: Mental accounting of savings and debt. Marketing Science, 17, 4-28. http://doi.org/b8rsrd 
Raut, U. and Brito, P. (2014) 'An Analysis of Brand Relationship with the Perceptive of Customer Based Brand Equity Pyramid' Universidade do Porto, Faculdade de Economia do Porto, 26.

Shao, W., Grace, D., \& Ross, M. (2019). Investigating brand visibility in luxury consumption. Journal of Retailing and Consumer Services, 49, 357-370.

Singer, L. (1966) Daydreaming: an introduction to the experimental study of inner experience, New York: Random House.

Statista (2020) Luxury Fashion; United Kingdom; Statista Market Forecast. [ONLINE] Available at https://www.statista.com/outlook/21030000/156/luxury-fashion/united-kingdom. (Accessed $2^{\text {nd }}$ December 2020).

Statista (2020) Global Personal Luxury Goods Industry-Statistics and Facts. [ONLINE] Available at https://www.statista.com/topics/1110/global-luxury-goods-industry/. (Accessed $2^{\text {nd }}$ December 2020).

Stokburger-Sauer, N. and Teichmann, K. (2013) 'Is luxury just a female thing? The role of gender in luxury brand consumption', Journal of business research. 66(1), pp. 889-896.

Strauss, A. and Corbin, J. (1998), Basics of Qualitative Research - Techniques and Procedure for Developing Grounded Theory, Sage, Thousand Oaks, CA.

Srinivasan, R., Srivastava, R. K., \& Bhanot, S. (2014). A Study of the antecedents of purchase decision of luxury brands. Journal of Business and Management,(16/5), May, 99-101..

Thaler, R. (1980). Toward a positive theory of consumer choice. Journal of Economic Behavior \& Organization, 1, 39-60. http://doi.org/cmjq7d

The Business of Fashion BOF (2018) The Great British Break-up: How Brexit will impact fashion in 2018. Available at https://www.businessoffashion.com/articles/intelligence/brexitfashion-2017-british-break-up (Accessed: $4^{\text {th }}$ September, 2018). 
Veblen, T. (1899) The theory of the leisure class. Houghton Mifflin, Boston

Veblen, T. (1902) The theory of the leisure class. New York: Macmillan

Wallpach, S., Hemetsberger, A., Thomsen, T. and Belk, R. (2020) Moments of luxury - A qualitative account of the experiential essence of luxury', Journal of Business Research, 116, pp. 491-502

Wang, Y. and Griskevicius, V. (2014) 'Conspicuous Consumption, Relationships and Rivals: Women's luxury products as signals to other women', Journal of consumer research. 40(10), pp.834-888.

Wilcox, K., Kim, H. and Sen, S. (2009) 'Why do consumers buy counterfeit luxury brands?' Journal of marketing research, 46(2), pp. 247- 259.

Wood, S. and Bettman, J. (2007) 'Predicting happiness: How normative feeling rules influence (and even reverse) durability bias', Journal of Consumer Psychology, 17(1), pp. 188-201.

Woods, W. A. (1960) Psychological dimensions ofconsumer decision,Journal of Marketing,24(3), 15-19

Yeoman, I. and McMahon-Beattie, U. (2010) The changing meaning of luxury. In: I. Yeoman and U. McMahon-Beattie (eds.) Revenue Management: A Practical Pricing Perspective, Chapter 6, Basingstoke, UK: Palgrave MacMillan, pp. 62-85.

Yeomen, I. (2011) 'The changing behaviours of luxury consumption', Journal of revenue and pricing management, 10(1), pp. 47-50.

Zhong, Y. and Mitchell, R. (2012) 'Does consumer well-being affect hedonic consumption', Psychology and marketing, 29(8), pp. 584-594. 
